\title{
PUSAT MODE DI KOTA PONTIANAK DENGAN KONSEP CITY WALK
}

\author{
Rhisma Aulia Ahmad ${ }^{1}$ Irwin $^{2}$, Yudi Purnomo ${ }^{3}$ \\ ${ }^{1}$ Mahasiswa, Program Studi Arsitektur, Fakultas Teknik, Universitas Tanjungpura. \\ overdose.raa@gmail.com \\ ${ }^{2}$ Program Studi Arsitektur, Fakultas Teknik, Universitas Tanjungpura \\ ${ }^{3}$ Program Studi Arsitektur, Fakultas Teknik, Universitas Tanjungpura
}

Naskah diajukan pada: 2 Februari 2021

Naskah revisi akhir diterima pada: 4 Februari 2021

\begin{abstract}
Abstrak
Masyarakat Provinsi Kalimantan Barat memiliki minat yang besar terhadap mode. Hal ini dapat dilihat dari banyaknya fasilitas yang tersedia untuk memenuhi kebutuhan mode dan munculnya bibit-bibit perancang muda di bidang mode, khususnya di Kota Pontianak. Hal ini tentunya harus diimbangi dengan edukasi tentang dasar-dasar pengetahuan dan teknik perancangan mode agar menghasilkan perancang yang lebih berkualitas, serta didukung fasilitas pemasaran dan promosi untuk mengembangkan kreatifitas pelaku mode. Pusat Mode menjadi alternatif untuk membuat segala kegiatan mode dapat dilaksanakan dalam satu lokasi, terkait kegiatan komersil, promosi, edukasi dan produksi untuk mewadahi tempat bagi pelaku mode untuk bekerja serta kreasi yang menarik bagi pengunjung khususnya daerah Kota Pontianak. Proses perancangan Pusat Mode menggunakan metode J.C. Jones yang dimulai dari sebuah gagasan yang dilengkapi dengan informasi, kemudian dianalisis untuk menghasilkan konsep-konsep yang sesuai gagasan awal dan kemudian di evaluasi. Konsep dalam perancangan merupakan semi-outdoor dengan penataan ruang dan perletakan jalur sirkulasi yang saling terhubung. Penyediaan ruang terbuka hijau di sekitar jalur sirkulasi.
\end{abstract}

Kata-kata Kunci: Mode, Pusat Mode, City Walk, Kota Pontianak

\begin{abstract}
The people of West Kalimantan Province have a great interest in fashion. This can be seen from the many facilities available to meet the needs of fashion and the emergence of young designers in the fashion sector, especially in Pontianak City. This of course must be balanced with education about the basics of fashion design knowledge and techniques in order to produce higher quality designers, and supported by marketing and promotion facilities to develop the creativity of fashion actors. The Fashion Center is an alternative to making all fashion activities carried out in one location, related to commercial activities, promotion, education and production to accommodate a place for fashion actors to work as well as interesting creations for visitors, especially in the Pontianak City area. The design process of the Fashion Center uses the J.C. Jones, who starts with an idea that is equipped with information, is then analyzed to produce concepts that match the initial idea and then evaluated. The concept in the design is semi-outdoor with interconnected spatial arrangement and placement of circulation paths. Provision of green open space around the circulation path.
\end{abstract}

Keywords: Fashion, Fashion Center, City Walk, Pontianak City

\section{Pendahuluan}

Perkembangan dalam dunia mode semakin maju dengan adanya perkembangan teknologi informasi dan komunikasi yang semakin pesat yang membuat pengetahuan masyarakat akan mode semakin banyak dan menimbulkan adanya perubahan gaya hidup. Sehingga manusia mulai merubah gaya hidup yang dijadikan sebagai wujud ekspresi diri pada suatu individu atau kelompok. Minat untuk mengikuti tren mode sudah besar bagi masyarakat Kota Pontianak. Hal ini dapat dilihat dari tersedianya fasilitas-fasilitas yang ada di bidang mode dapat dilihat dari banyak nya toko busana dan 
aksesoris, serta pusat perbelanjaan seperti Ayani Megamall dan Ramayana, les privat menjahit, salon, barber shop, dan mulai banyaknya merek lokal yang mulai muncul di Kota Pontianak.

Berdasarkan Badan Pusat Statistik Kota Pontianak (2019) dalam data Pertumbuhan Produk Domestik Regional Bruto Kota Pontianak tahun 2014-2018 menyatakan pada kategori industri pengolahan, Industri tekstil dan pakaian jadi mengalami laju pertumbuhan terbesar, yakni sebesar 7,23\%. Hal ini menunjukkan Kota Pontianak berpotensi untuk mengembangkan industri dan perdagangan di bidang mode. Pusat Mode ditujukan untuk menjadi pusat perbelanjaan bagi pemasaran untuk segala kebutuhan mode baik mode tradisional ataupun mode internasional bagi masyarakat khususnya di Kota Pontianak. Kegiatan mode dalam satu lokasi atau tempat dimaksudkan agar memudahkan pelaku usaha dalam proses jual beli produk serta dapat saling bertukar ide dengan pelaku usaha lainnya, juga agar pengunjung tidak perlu berkeliling ke banyak tempat untuk berbelanja terkait mode yang tentunya memakan banyak waktu, tenaga, dan biaya.

Penggunaan konsep City Walk pada perancangan pusat mode ini cukup sesuai untuk mendukung fungsi bangunan sebagai pusat kegiatan mode. Konsep City Walk merupakan pedestrian yang menghubungkan antar bangunan atau fasilitas yang tersedia. Konsep City Walk ini juga diharapkan akan memberikan suasana yang berbeda bagi pengunjung dengan perbelanjaan mode lainnya di Kota Pontianak, karena berkonsep sebagai pedestrian sekaligus ruang terbuka hijau yang memberikan nuansa asri dan rindang pada perancangan Pusat Mode ini. Konsep City Walk ini akan membuat pengunjung mendapatkan nuansa pengalaman beraktivitas berbelanja sekaligus refreshing dan rekreasi di Pusat Mode Kota Pontianak ini.

\section{Kajian Pustaka}

Menurut Kamus Besar Bahasa Indonesia (2020), pusat adalah pokok pangkal atau yang menjadi pumpunan berbagai hal, urusan, dan sebagainya. Secara etimologi menurut Malcolm Barnard (2007), mode/ fashion berasal dari Bahasa Latin yaitu "factio", yang berarti "melakukan". Kemudian dalam perkembangannya, kata factio tersebut diserap ke dalam Bahasa Inggris menjadi "fashion" yang kemudian secara sederhana diartikan sebagai gaya pakaian yang popular dalam suatu budaya. Berdasarkan Kamus Besar Bahasa Indonesia (2020), mode didefinikan sebagai ragam, cara atau bentuk yang terbaru pada suatu waktu tertentu tentang pakaian, potongan rambut, corak hiasan, dan sebagainya.

Menurut Book Review: The Fashion of Architecture, dalam Wijaya (2010) menyatakan bahwa fashion center adalah sebuah wadah tempat untuk para pelaku yang terkait dapat bekerja sama, berkoordinasi dengan baik dan dapat mencapai pasar dengan baik pula. Hal tersebut melibatkan pemasaran, promosi, perancang, pengembang desainer, dan pihak terkait seperti model para produsen dalam bidang textile, penjahit, dan lain sebagainya.

Menurut Krisnawati (2013), City Walk diartikan sebagai jalur bagi pejalan kaki dalam peristilahan urban design termasuk path (jalan), yang menghubungkan node (bisa berupa fasilitas umum, ataupun simpul moda lalu lintas), district (berupa kawasan) terdekat. City Walk dalam realisasinya terbagi menjadi tiga macam sistem penerapan City Walk yaitu outdoor, indoor, dan semi-outdoor. Eny Krisnawati juga mengatakan City Walk ini biasanya merupakan koridor ruang terbuka untuk pejalan kaki yang menghubungkan beberapa fungsi komersial dan retail dengan ukuran berkisar $2-6$ meter. Koridor ini juga dimanfaatkan sebagai ruang berkumpul atau ruang tunggu bagi pengunjung, tergantung konsep jenis kegiatan yang akan diciptakan.

\section{Metode}

Metode perancangan dalam penulisan tugas akhir yang berjudul pusat kegiatan mode ini mengambil metode perancangan menurut J.C. Jones (Nuraini dan Sudrajat, 2010). Perancangan Pusat Mode ini bermula dari munculnya suatu ide atau gagasan terlebih dahulu kemudian dikumpulkan data sebagai penguat gagasan. Semua data dianalisis, kemudian disintesiskan untuk 
menghasilkan konsep-konsep yang sesuai gagasan awal dan kemudian di evaluasi. Tahap evaluasi ini akan memudahkan proses perancangan.

\section{Tahap gagasan}

Tahap gagasan dimulai dengan penentuan judul Pusat Mode yang didapatkan dari isu dan kebutuhan yang dijabarkan ke dalam latar belakang, permasalahan, rumusan masalah, tujuan, sasaran, manfaat dan lingkup pembahasan.

\section{Tahap Tinjauan Teoritis}

Tinjauan teori yang dikaji berupa pengertian mode, pengertian menurut ahli, sejarah perkembangan mode, jenis-jenis mode, kegiatan utama di bidang permodean, kemudian pembahasan tentang para pelaku yang terlibat dalam kegiatan mode.

\section{Tahap Pengumpulan Data}

Tahap pengumpulan data dilakukan guna menguatkan gagasan dan ide diawal. Terdapat empat jenis metode pengumpulan data yang dilakukan, diantaranya studi literatur, studi preseden, studi lapangan, dan dokumentasi. Studi literatur guna mencari data dari literatir melalui buku, jurnal, dan bahan tertulis lainnya. Studi preseden dilakukan guna sebagai acuan perancangan jika ruang atau fasilitas yang dibutuhkan belum terdapat standarnya. Studi lapangan guna memperoleh data mengenai rencana lokasi perencanaan. Terakhir dokumentasi, dilakukan untuk mendokumentasikan kondisi eksisting lokasi perancangan.

\section{Tahap Analisis}

Data-data yang dikumpulkan akan dianalisis guna menemukan solusi dan pemecahan masalah pada perancangan. Adapun data yang dianalisis di antaranya analisis tapak, analisa studi kasus Pusat Mode, analisis pengguna, analisis pengguna, analisis program ruang, analisis utilitas, analisis struktur, dan analisis bentuk.

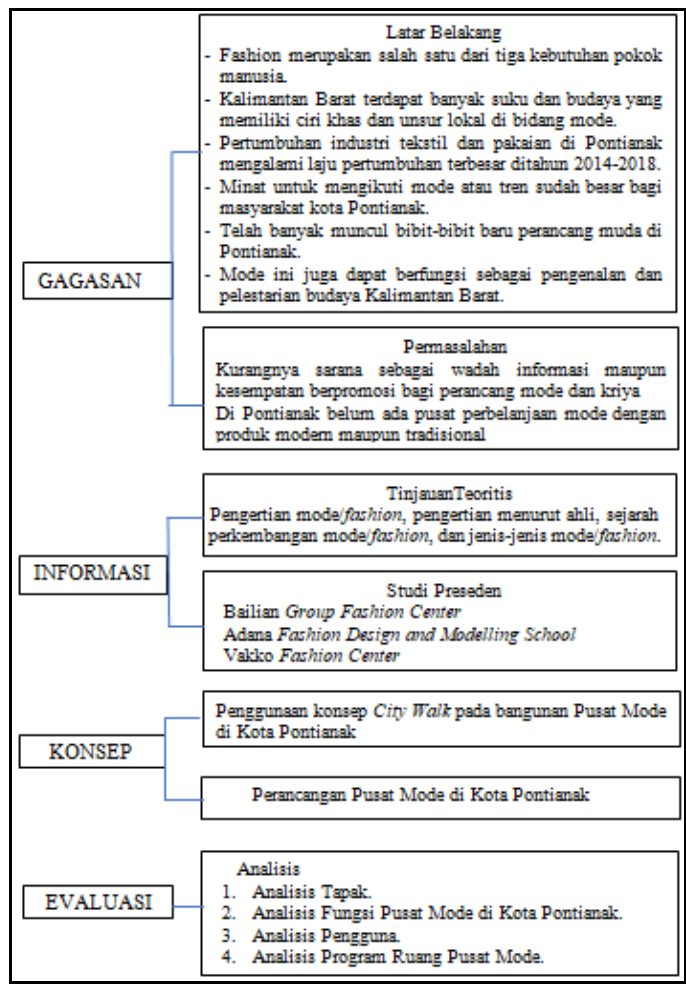

Gambar 1. Diagram alir perancangan Pusat Mode Pontianak

Sumber: Penulis, 2020 


\section{Hasil dan Pembahasan}

Pembahasan ini akan dimulai dari menentukan lokasi perancangan, kemudian analisa dari landasan konseptual, sehingga didapatlah hasil perancangan Pusat Mode di Kota Pontianak dengan konsep City Walk.

\section{Lokasi Perancangan}

Pusat Mode di Kota Pontianak merupakan bangunan dengan fungsi perdagangan dan jasa. Pusat Mode ini melayani seluruh wilayah Kota Pontianak dan akan dikelola oleh swasta. Maka Pusat Mode ini akan diletakkan di lokasi yang diperuntukkan untuk perdagangan jasa maupun kawasan permukiman yang dekat dengan kawasan perdagangan dan jasa. Lokasi terpilih untuk perancangan Pusat Mode di Kota Pontianak berada di Jl. Dr. Wahidin S. Kecamatan Pontianak Kota, Kota Pontianak, Kalimantan Barat. Memiliki luas site $\pm 35.000 \mathrm{~m}^{2}$ yang mana peruntukan lahannya sudah sesuai menurut RTRW Kota Pontianak Tahun 2013-2033 sebagai kawasan untuk perdagangan dan jasa. Kondisi aksesibilitas baik karena jalan Dr. Wahidin S. ini merupakan jenis jalan lokal sekunder (K3) yang di lewati kendaraan mobil, truk, bus, angkutan umum, sepeda dan motor. Lokasi berada tidak terlalu berjauhan dengan kawasan perbelanjaan lainnya terkait mode. Gambaran lokasi perancangan Pusat Mode ini dapat dilihat di Gambar 2.

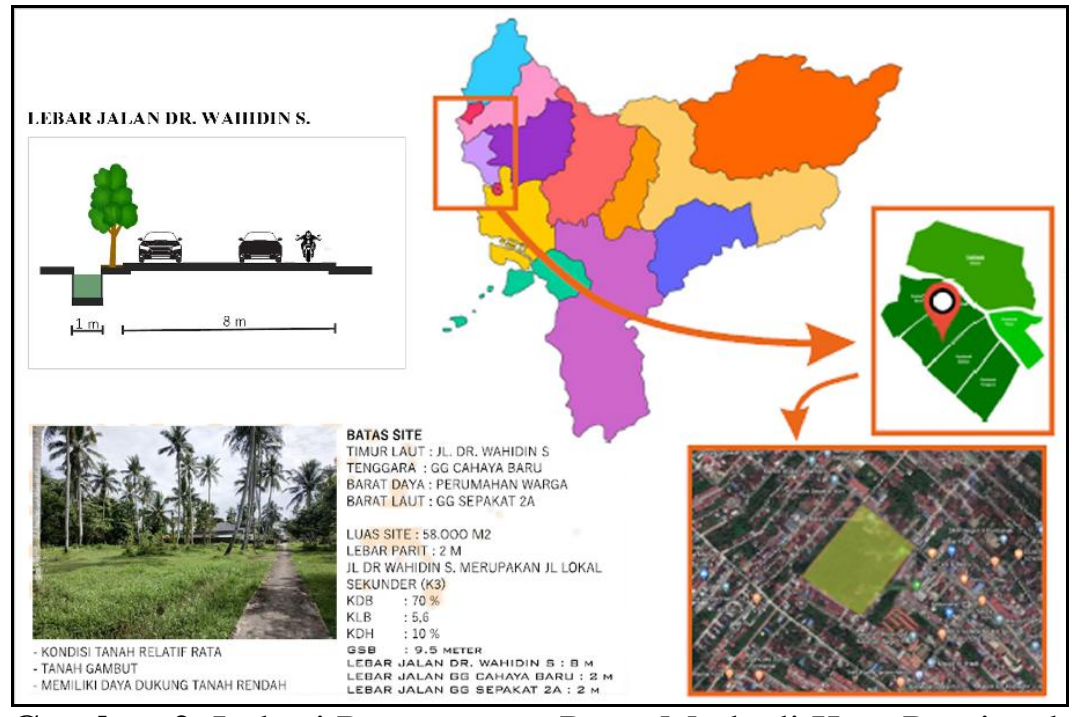

Gambar 2. Lokasi Perancangan Pusat Mode di Kota Pontianak

Sumber: Penulis, 2020

\section{Landasan Konseptual}

Landasan Konseptual adalah proses analisis dari data-data yang telah dikumpulkan sebelumnya untuk mendapatkan hasil perancangan yang sesuai. Landasan konseptual ini terbagi menjadi lima analisa, yaitu analisa fungsi, analisis internal, analisa eksternal, analisa bentuk, analisa struktur, dan analisa utilitas. Fungsi perancangan ini terbagi menjadi fungsi utama dan penunjang. Fungsi utama Pusat Mode ini adalah menjadi suatu wadah yang dapat mewadahi kegiatan mode terkait kegiatan pemasaran hasil karya baik modern maupun tradisional (komersil) yang dilengkapi fasilitas penunjang berupa fasilitas untuk memperkenalkan hasil karya (promosi), tersedianya fasilitas belajar seperti kursus dan seminar (edukasi), terakhir dapat digunakan sebagai tempat rekreasi yang menarik bagi pengunjung. Namun, tetap dapat di gunakan bagi pelaku usaha awal atau kecil jadi bangunan ini dapat digunakan secara efisien dan berjalan sesuai fungsinya.

Untuk analisa internal terdapat empat analisis, yaitu tahapan analisis pelaku, analisis kegiatan dan kebutuhan ruang, analisis hubungan ruang dan organisasi ruang, analisis persyaratan ruang dan besaran ruang Analisa pelaku dapat dilihat pada Gambar 3. 


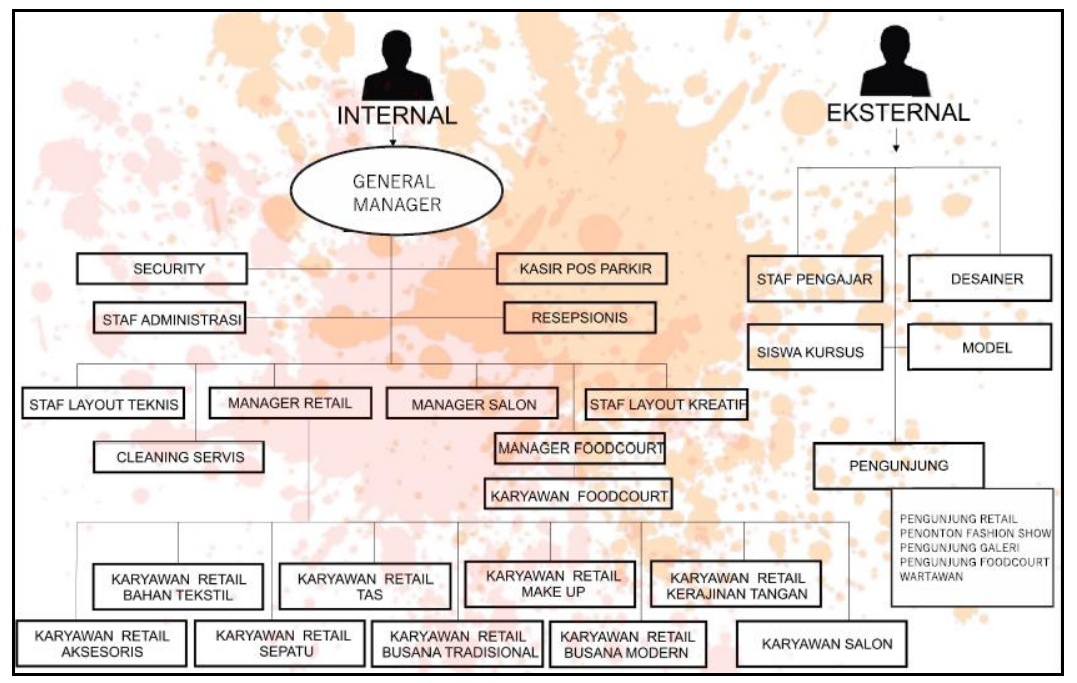

Gambar 3. Skema Pelaku Kegiatan di Pusat Mode Pontianak

Sumber: Penulis, 2020

Kegiatan-kegiatan yang diwadahi pada Pusat Mode dibagi menjadi dua yaitu kegiatan utama dan kegiatan penunjang. Analisa kegiatan dan kebutuhan ruang ini diperlukan untuk memenuhi kebutuhan akan ruang-ruang dan program ruang yang digunakan di perancangan Pusat Mode ini. Kegiatan utama Pusat Mode di Kota Pontianak ini adalah kegiatan memasarkan produk atau karya (komersil) yaitu kegiatan jual dan beli, memilih produk yang dipasarkan, transaksi. Selanjutnya kegiatan edukasi berupa kursus mode dimana akan ada kegiatan belajar mengajar, merancang, praktek produksi, fitting produk, dan pengemasan produk. Kemudian ada promosi berupa peragaan busana dan galeri yang akan ada kegiatan peragaan busana, penjurian, menonton acara, fotografi dan modelling. Sementara untuk kegiatan penunjang ada kegiatan pengelolaan gedung terkait administrasi, kebersihan dan keamanan, serta kegiatan melayani dan mengawasi pengunjung. Setelah mendapatkan data yang ada, ruang-ruang akan dihubungkan sesuai sifat ruang dan jenis kegiatan yang serupa atau berkaitan satu sama lain sehingga didapatkan suatu organisasi ruang yang dapat dilihat di Gambar 4.

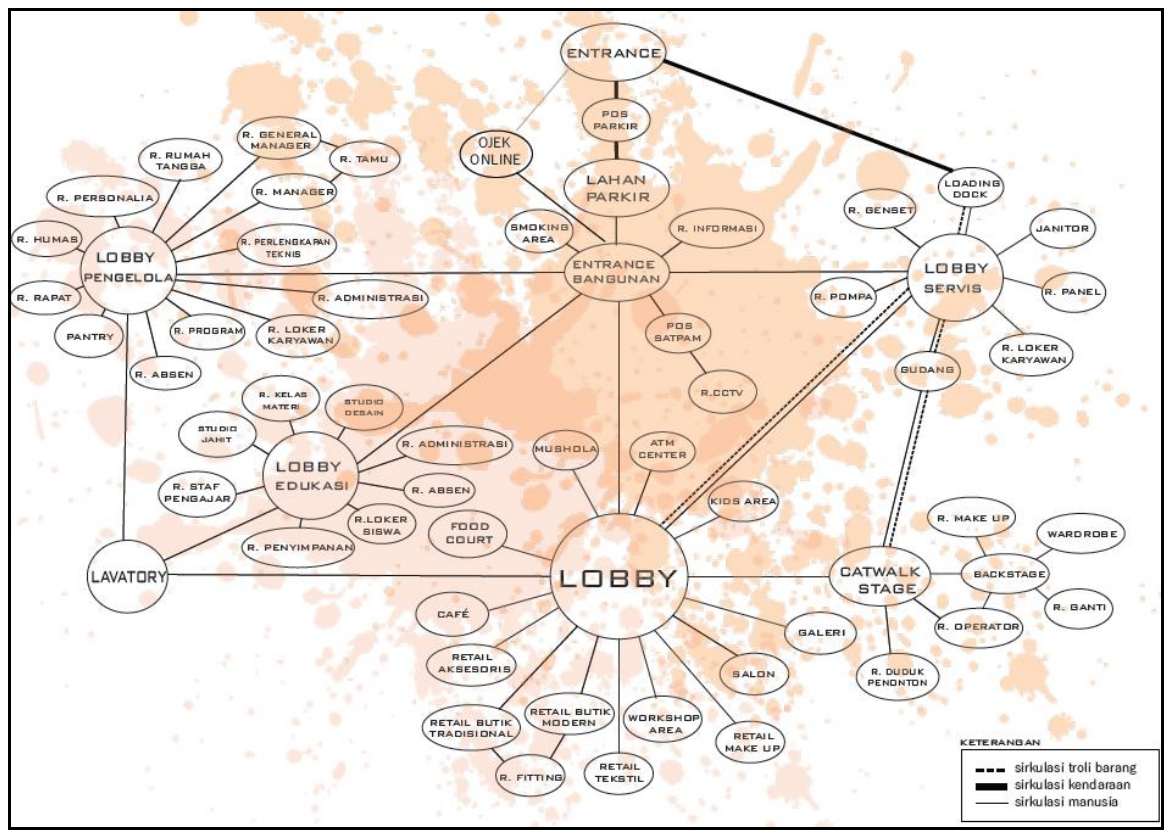

Gambar 4. Organisasi Ruang Pusat Mode Kota Pontianak Sumber: Penulis, 2020 
Perletakan bangunan Pusat Mode di Kota Pontianak ini diletakkan di tengah site untuk memberikan ruang di sekeliling site untuk ditanami vegetasi yang berfungsi melindungi bangunan dari sinar matahari sore. Analisa perletakan ini dapat dilihat di Gambar 5.

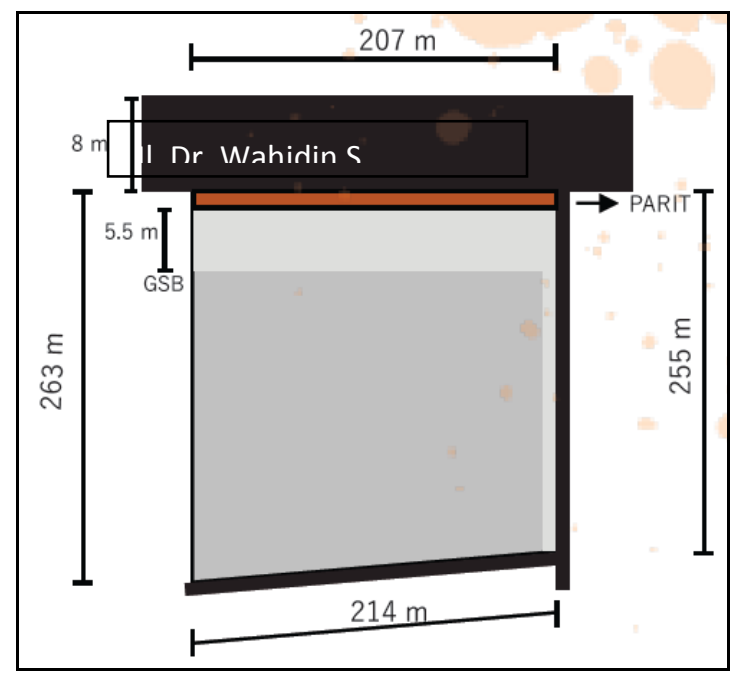

Gambar 5. Analisa Perletakan Pusat Mode di Kota Pontianak

Sumber: Penulis, 2020

Untuk orientasi bangunan ini mengarah ke arah jalan utama, yaitu menghadap ke jalan Dr. Wahidin S. agar memudahkan masyarakat melihat bangunan Pusat Mode ini. Berdasarkan analisa terhadap panca indera yaitu di sisi Timur Laut site (depan site) lebih ramai orang yang berlalu lalang. Analisa orientasi ini dapat dilihat di Gambar 6.

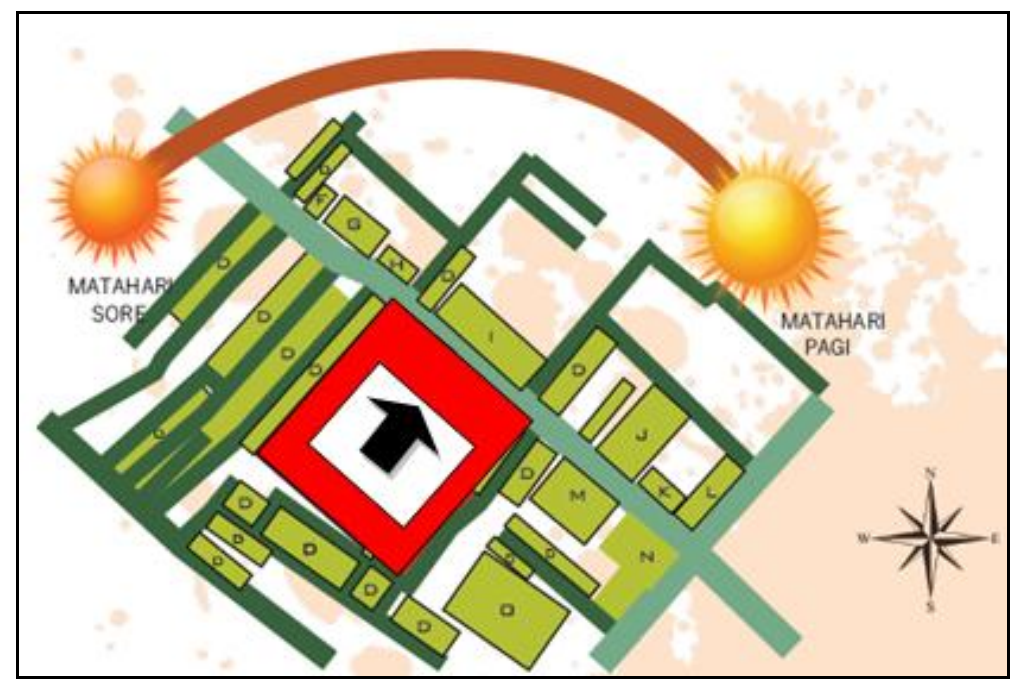

Gambar 6. Analisa Orientasi Pusat Mode di Kota Pontianak Sumber: Penulis, 2020

Jalur sirkulasi didalam site dibuat mengitari bangunan, guna kemudahan akses ke dalam bangunan dan baik untuk keperluan servis maupun jalur pemadam kebakaran. Akses masuk utama pada site bangunan adalah jalan Dr.Wahidin S. jalan utama, jalan lebih mudah diakses, sirkulasi padat (berada di dekat pasar). Analisa sirkulasi ini dapat dilihat di Gambar 7. 


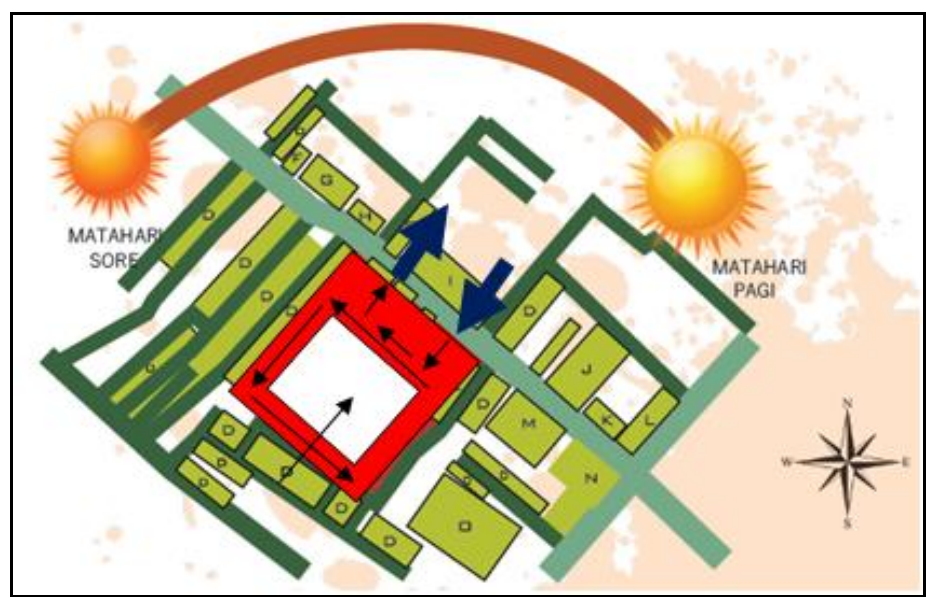

Gambar 7. Analisa Sirkulasi Pusat Mode di Kota Pontianak Sumber: Penulis, 2020

Vegetasi di area barat site akan ditamani vegetasi peneduh untuk mengurahi paparan sinar matahari sore ke bangunan. Untuk pohon peneduh sekaligus pengarah yang sudah ada di tepi jalan raya akan tetap dibiarkan ada. Untuk area depan site ditanami tumbuhan perdu atau tanaman yang tidak menghalangi view ke bangunan dari jalan raya. Analisa vegetasi ini dapat dilihat di Gambar 8.

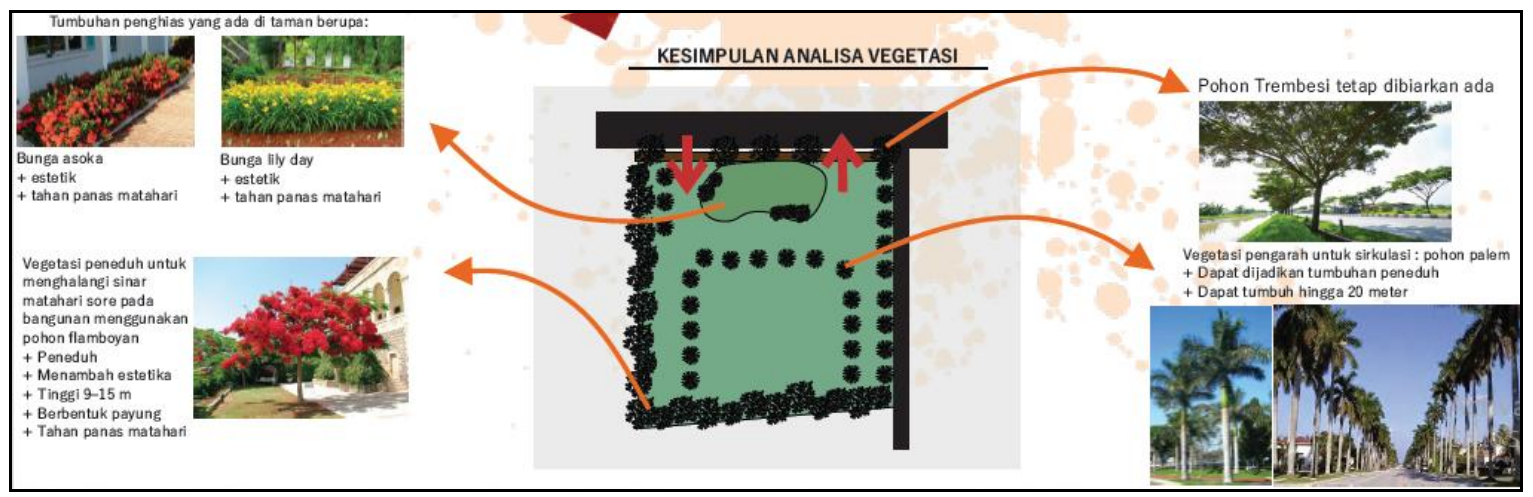

Gambar 8. Analisa Vegetasi Pusat Mode di Kota Pontianak Sumber: Penulis, 2020

Area servis diletakkan di sisi site yang paling banyak terkena langsung sinar matahari sore, karena area servis merupakan tempat yang pengunaannya tidak selama dengan fungsi lainnya. Area Semi Publik diletakkan di area tengah site agar dekat dengan parkiran pengunjung dan pengelola sehingga aksesnya lebih mudah. Area privat membutuhkan tingkat privasi yang lumayan tinggi seperti kebisingan yang rendah dan akses yang langsung sehingga membuat area privat ini diletakkan berjarak dengan area publik dan diletakkan di area yang terkena matahari pagi. Area publik diletakkan di depan site atau di area yang dapat dengan mudah dilihat dan diakses pengunjung.

Bentuk yang digunakan pada Pusat mode Kota Pontianak ini berasal dari konsep mode itu sendiri yang memiliki sifat dinamis dan tidak terbatas, sehingga bentuk yang diambil adalah berawal dari lambang infinity (tidak terbatas) dan bentuk lambangnya yang dinamis juga sesuai dengan konsep mode. Bentuk ini diterapkan pada penyusunan ruang dan massa bangunan Pusat Mode. Bentukan Pusat Mode ini ditata dengan konsep terpusat yang titik pusat nya merupakan ikon dan kegiatan utama pada Pusat Mode yaitu peragaan busana. Bentuk pusat mode ini juga di buat banyak massa bangunan dan banyak sirkulasi untuk memenuhi konsep City Walk. Konsep ini juga menjadikan akan banyak ruang-ruang berkumpul dan area taman untuk memberikan nuansa rindang dan asri agar para pengunjung dapat tetap merasa nyaman saat berbelanja dengan berjalan-jalan kaki karena sekeliling bangunan yang teduh. Analisa bentuk Pusat Mode ini dapat dilihat di Gambar 9. 


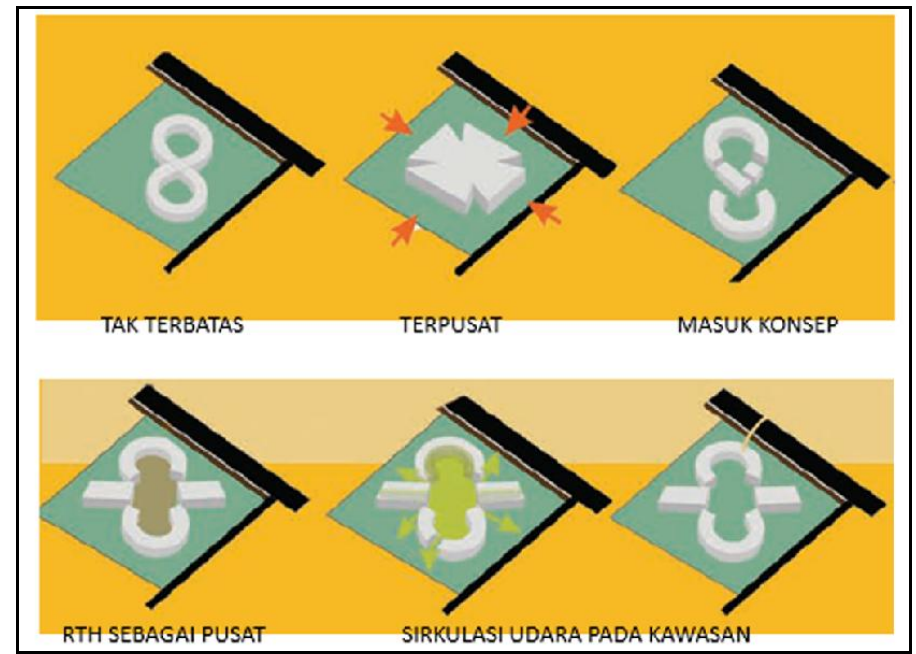

Gambar 9. Analisa Bentuk Pusat Mode di Kota Pontianak

Sumber: Penulis, 2020

Analisa konsep struktur dibagi menjadi dua bahasan, struktur bawah dan struktur atas. Struktur bawah merupakan struktur yang menopang seluruh beban pada bangunan, yaitu pondasi yang menggunakan pondasi tiang pancang beton. Sedangkan struktur atas merupakan struktur yang berada di atas permukaan tanah, meliputi dari kolom, balok, plat lantai, dinding dan rangka atap. Kolom dan balok memiliki struktur beton bertulang, untuk plat lantai beton menggunakan penutup lantai berupa keramik, dinding menggunakan susunan bata ringan, kemudian rangka atap merupakan rangka atap dari baja ringan dengan penutup atap lembaran besar berbahan galvalum.

Analisa utilitas pada perancangan Pusat Mode di Kota Pontianak ini terdiri dari beberapa sistem, diantaranya sistem jaringan air kotor, sistem jaringan, sistem tata udara, sistem keamanan bangunan, dan sistem transportasi bangunan. Air bersih pada perancangan ini berasal dari Perusahaan Daerah Air Minum (PDAM) yang ditampung di ground tank dan kemudian dialiri ke ruang-ruang lavatory dan dapur menggunakan sistem up feed dengan bantuan pompa air. Sedangkan untuk jaringan air kotor yang berasal dari toilet akan diteruskan ke septic tank dan diolah menggunakan sewage treatment plant (STP) sebagai pengolahan akhir kotoran sebelum di salurkan ke roil kota. Untuk air kotor yang berasal dari wastafel akan diolah ke perangkap sabun sedangkan untuk limbah dari dapur akan di olah ke perangkap lemak yang kemudian dialiri ke riol kota.

Sumber utama energi listrik pada Pusat Mode ini berasal dari Perusahaan Listrik Negara (PLN). Terdapat juga cadangan sumber listrik dari generator set. Jaringan Informasi dan Komunikasi pada pusat mode mengacu pada jaringan tata suara, telepon dan internet. Untuk jaringan tata suara menggunakan sistem PA (Public Address Sound System). Sistem tata suara ini kemudian akan dikelola pada ruang peralatan dan ruang ME (Mechanical Electrical). CCTV yang ada di Pusat Mode ini dibagi menjadi dua jenis berdasarkan penempatannya, untuk diluar bangunan menggunakan CCTV kamera dome valdal proof sedangkan untuk bagian dalam bangunan menggunakan CCTV jenis Pan Tilt Zoom (PTZ).

Untuk sistem tata udara menggunakan penghawaan buatan yaitu AC sentral dengan jenis VRV. Kemudian untuk keamanan bangunan dari kebakaran menggunakan hidran, sprinkler, alat pemadam api ringan, detector asap, dan penangkal petir yang menggunakan sistem Franklin. Transportasi bangunan menggunakan tangga dan escalator guna mempermudah pengunjung untuk mencapai ruangan dengan cepat.

\section{Hasil Perancangan}

Hasil perancangan Pusat Mode di Kota Pontianak ini meliputi gambar siteplan, gambar denah lantai dasar dan lantai satu, gambar tampak, gambar potongan, gambar suasana eksterior dan interior 
bangunan. Pada gambar siteplan menjelaskan perancangan dengan konsep City Walk dengan massa yang terpisah-pisah dan saling dihubungkan dengan adanya sirkulasi semi-outdoor di sekelilingnya. Jalur sirkulasi ini difungsikan hanya untuk pejalan kaki yang berkunjung atau berbelanja. Pada siteplan ini juga menunjukkan akses masuk dan keluar dari Jalan Dr. Wahidin .Tersedia area parkir pengunjung dan pengelola yang terpisah. Untuk denah lantai dasar Pusat Mode di Kota Pontianak dapat dilihat di Gambar 10.

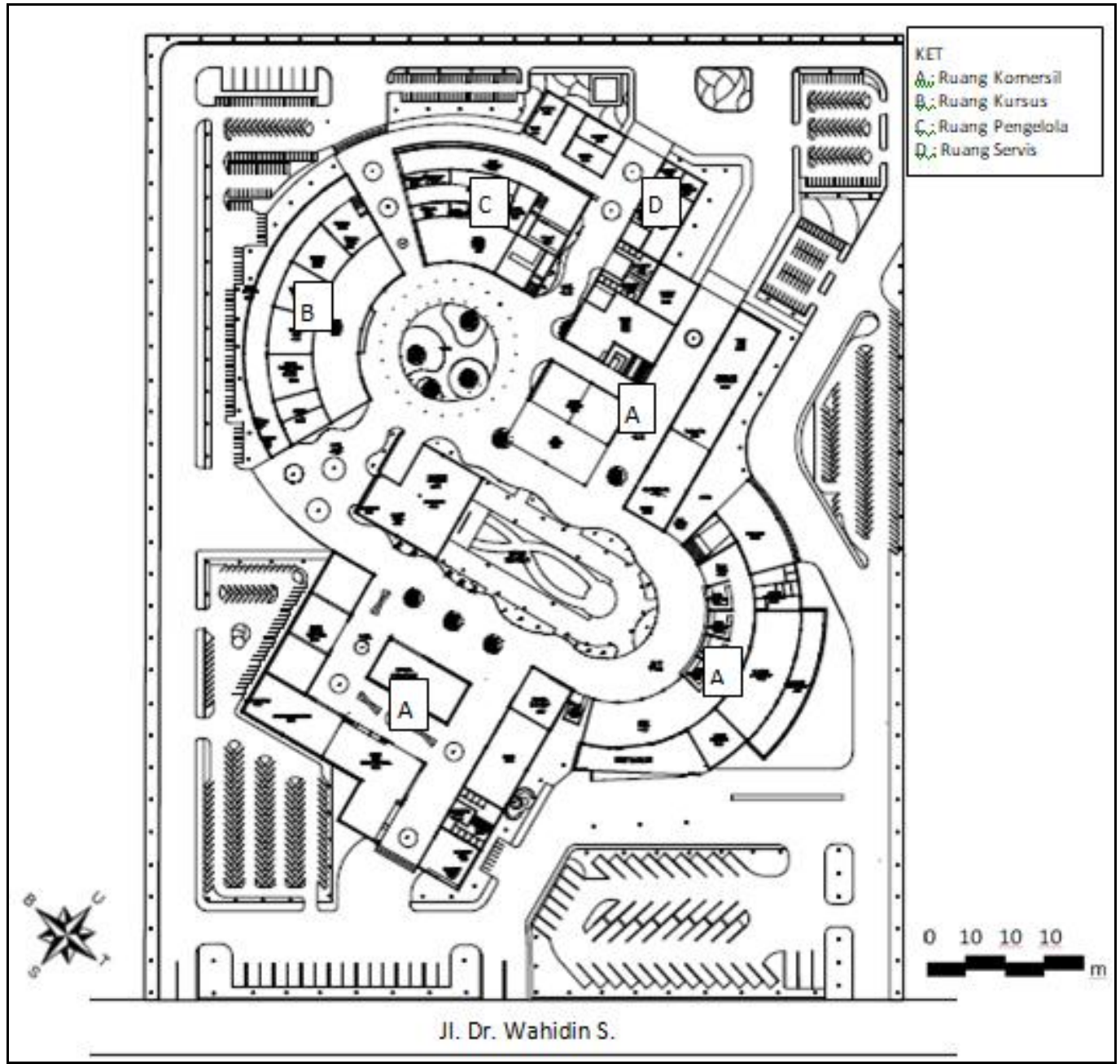

Gambar 10. Siteplan Pusat Mode di Kota Pontianak

Sumber: Penulis, 2020

Pada gambar denah lantai satu akan terlihat konsep bentuk dari lambang infinity yang telah dijelaskan pada analisa bentuk sebelumnya. Perwujudan dari lambang infinity ini diwujudkan dengan bentukan ruang-ruang dan jalur sirkulasi pada perancangan ini, yaitu terdapatnya ruang-ruang yang berbentuk setengah lingkaran dan jalur yang saling terhubung. Pada denah ini juga dapat menjelaskan ruang yang menjadi pusat dari Pusat Mode ini adalah ruang peragaan busana/ area fashion show dan ruang terbuka hijau berupa taman yang terdapat di lantai dasar. Di sekitar sirkulasi yang memiliki lebar 10 meter ini selain sebagai jalur sirkulasi pengunjung juga difungsikan sebagai area berjualan bagi stan-stan kecil berupa gerobak-gerobak yang menjual berbagai macam dagangan seperti cemilan dan minuman. Pada denah lantai satu ini dapat dilihat juga hubungan antar ruang-ruang yang terpisah berdasarkan fungsi dan jenis kegiatan yang ada, diantaranya komersil, edukasi, pengelola, dan servis. Ruang-ruang ini dipisah guna memberikan privasi antar ruang agar tidak saling terganggu dengan kegiatan lainnya. Dimana fungsi edukasi dan pengelola akan 
membutuhkan ruang dan akses masuk yang tersendiri karena sifat ruangnya semi publik, berbeda halnya dengan ruang-ruang komersil yang bersifat publik. Untuk denah lantai satu Pusat Mode di Kota Pontianak dapat dilihat pada Gambar 11.

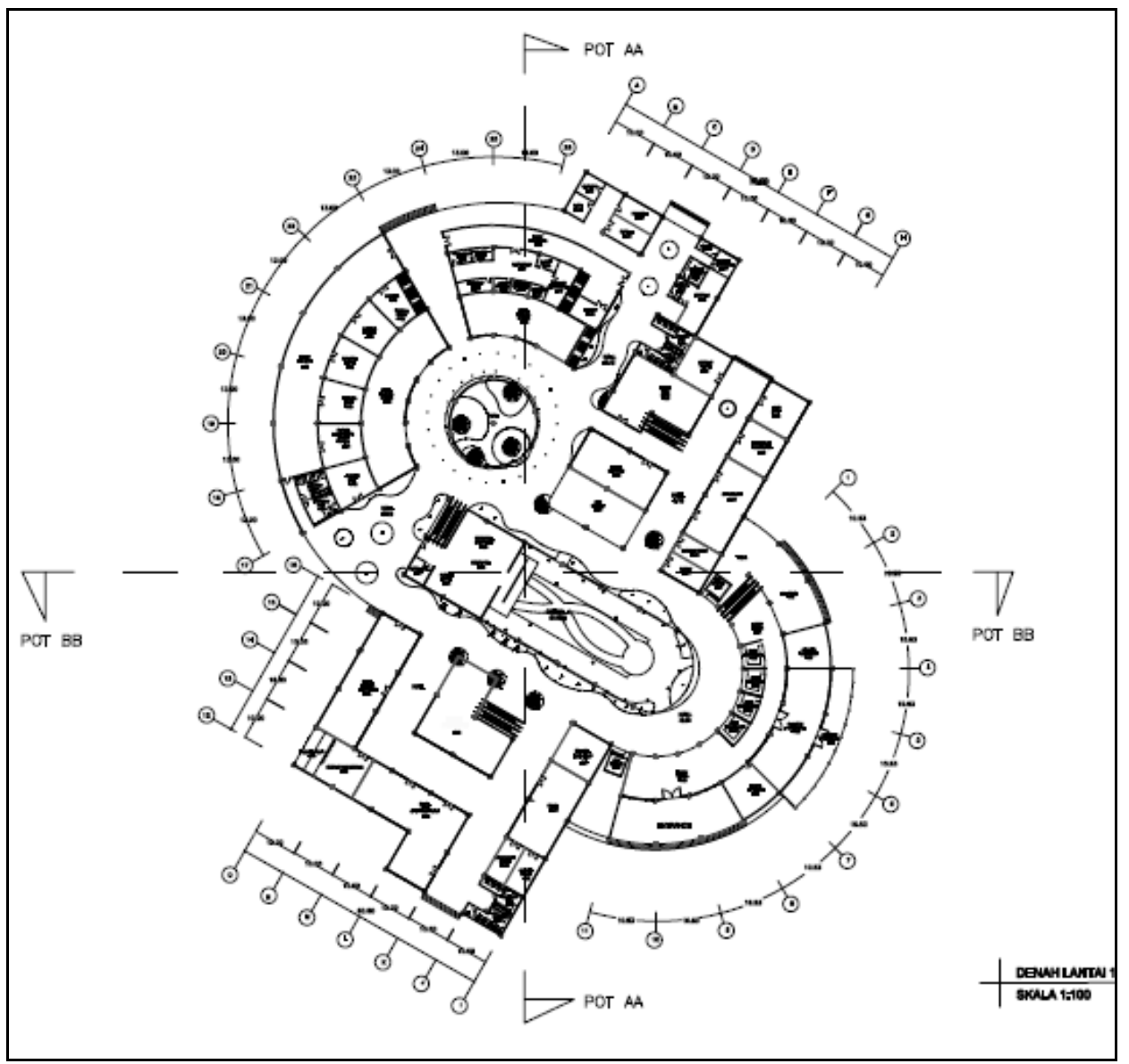

Gambar 11. Denah Lantai Dasar Pusat Mode di Kota Pontianak

Sumber: Penulis, 2020

Pada denah lantai dua ini terjadi pengurangan bentuk dan ruang yang telah disesuaikan dengan kebutuhan ruang. Pada area lantai dua ini juga memiliki jenis kegiatan yang beragam pula, sebagai lanjutan dari lantai satu. Jenis transportasi yang digunakan juga berupa eskalator guna memudahkan pengunjung menjangkau ruang-ruang di Pusat Mode ini.

Pada denah lantai tiga, tidak banyak ruang yang ada. Ruangan ini sebagai lanjutan dari lantai sebelumnya, yaitu ruang-ruang dengan fungsi komersil. Pada denah lantai tiga ini kita juga dapat melihat bentuk atap yang merupakan atap gerigi dengan bentuk setengah lingkaran. Bentuk atap seperti ini menyesuaikan dengan bentuk denah yang ada. Kemudian denah dengan bentuk persegi menggunakan atap miring dengan kemiringan yang bervariasi. Untuk denah lantai dua dan lantai tiga Pusat Mode di Kota Pontianak dapat dilihat di Gambar 12 dan 13. 


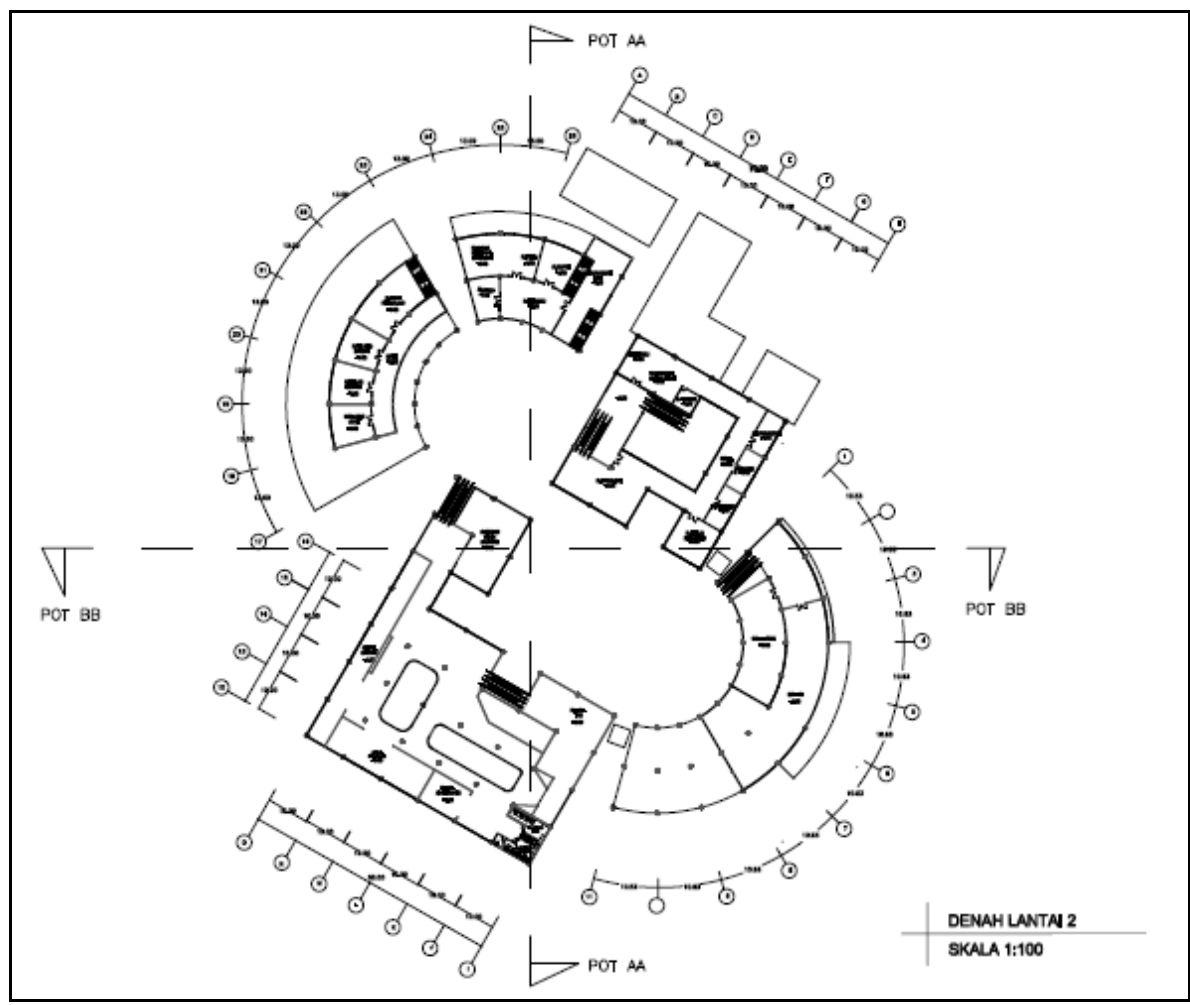

Gambar 12. Denah Lantai Satu Pusat Mode di Kota Pontianak Sumber: Penulis, 2020

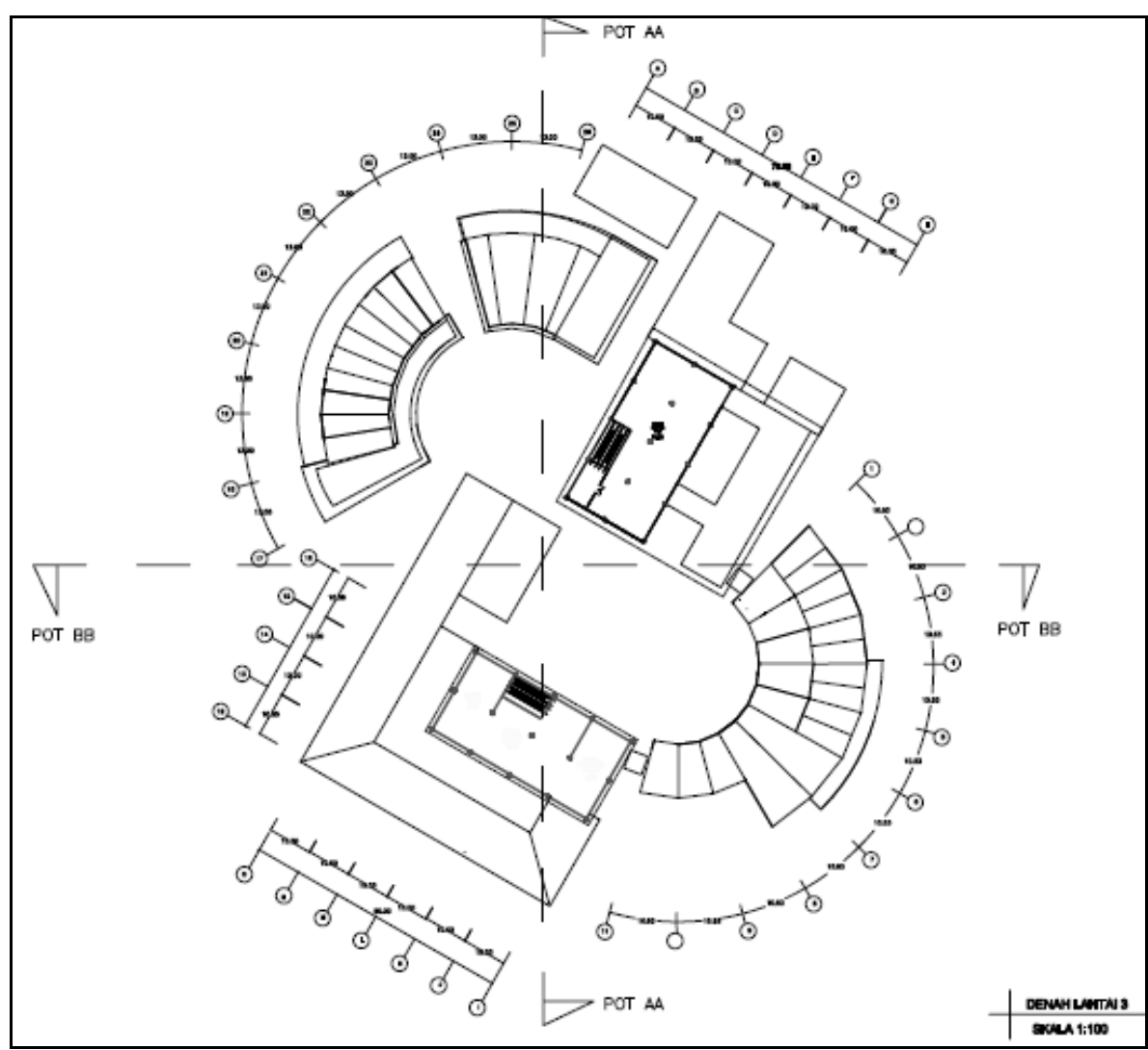

Gambar 13. Denah Lantai Dua Pusat Mode di Kota Pontianak Sumber: Penulis, 2020 
Pada gambar tampak ini akan menunjukkan tampilan/ fasad pada bangunan dari segala sisi (depan, kanan, kiri dan belakang). Dari tampak kita mengetahui bahwa bangunan pusat mode ini tidak terlalu tinggi, karena menekankan konsep kawasan dari City Walk. Pada bagian fasad bangunan tidak terlalu banyak ornamen dan sebagainya, karena lebih bermain pada bentukan dari denah nya itu sendiri. Tampak Pusat Mode di Kota Pontianak dapat dilihat di Gambar 14.

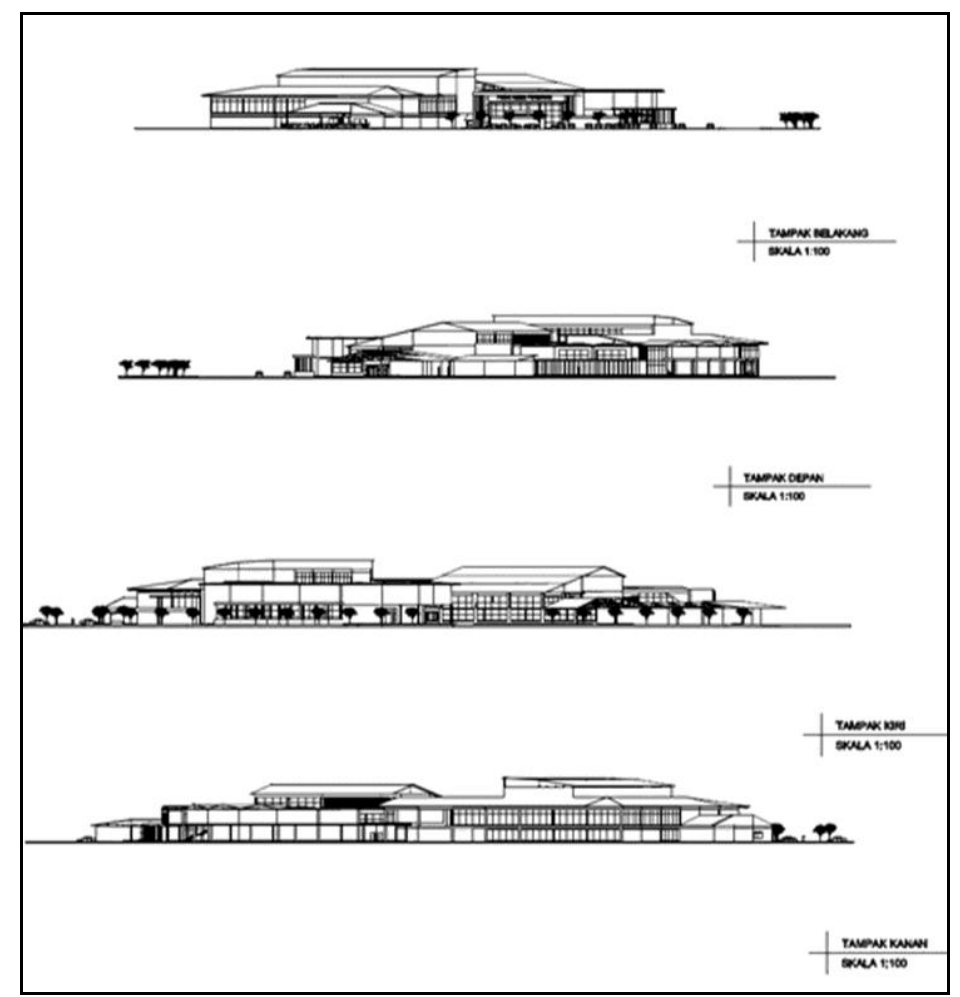

Gambar 14. Tampak Pusat Mode di Kota Pontianak Sumber: Penulis, 2020

Gambar potongan menunjukan konsep struktur yang digunakan. Karena potongan kawasan tidak terlalu jelas untuk memperlihatkan konsep struktur pada bangunan, maka akan dilampirkan potongan salah satu massa bangunan yang ada di perancangan ini. Potongan kawasan Pusat Mode di Kota Pontianak dapat dilihat pada Gambar 15. dan potongan bangunan dapat dilihat di Gambar 16.

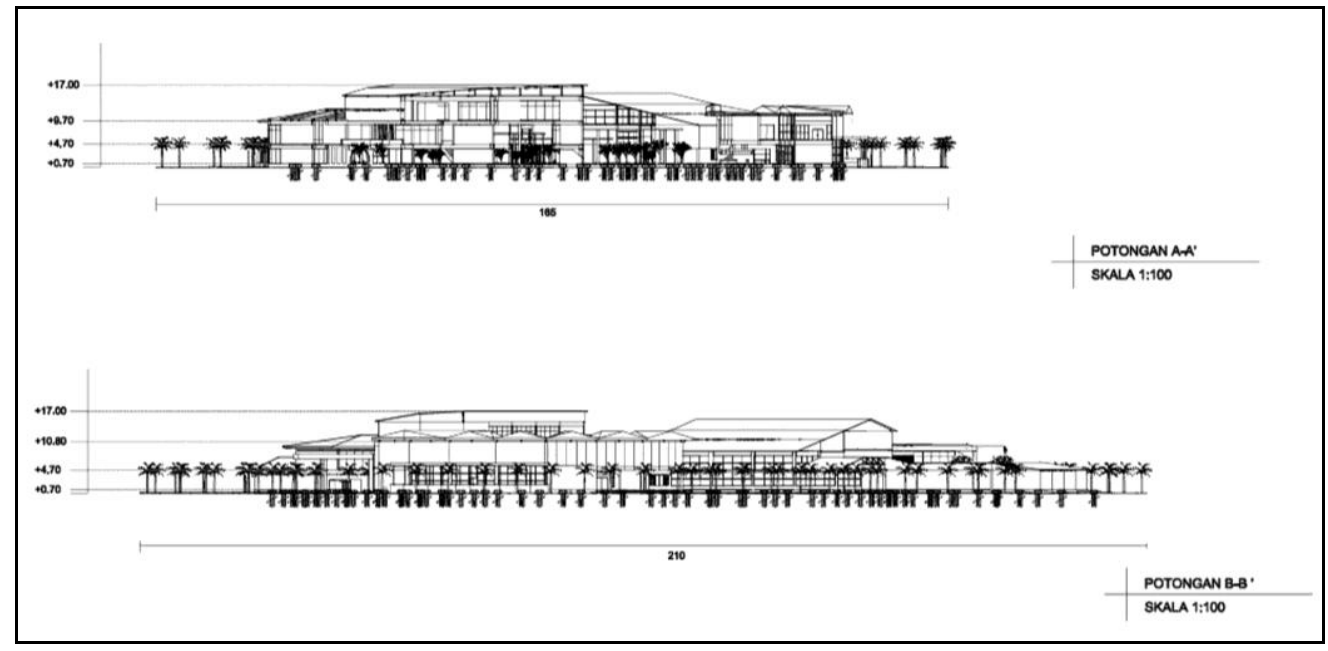

Gambar 15. Potongan Kawasan Pusat Mode di Kota Pontianak

Sumber: Penulis, 2020 


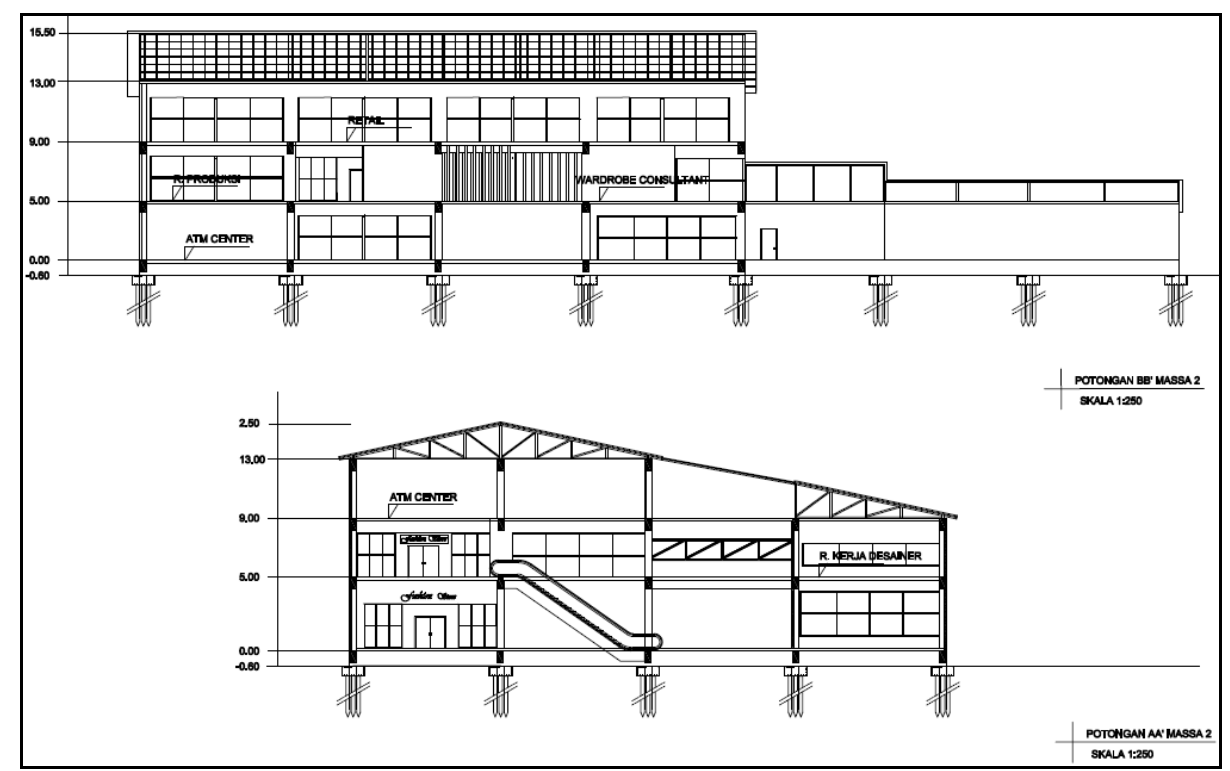

Gambar 16. Potongan Bangunan Pusat Mode di Kota Pontianak

Sumber: Penulis, 2020

Gambar suasana eksterior bangunan menunjukan aktivitas dan suasana di luar bangunan Pusat Mode di Kota Pontianak. Penggunaan konsep City Walk sendiri membuat bangunan dominan oleh jalur pedestrian dan membuat suasana lebih rindang dengan adanya ruang hijau di sekitar jalur pedestrian tersebut. Jalur-jalur sirkulasi yang ada juga bersifat semi-outdoor membuat nuansa lebih alami dengan lebih memanfaatkan penghawaan dan pencahayaan alami. Sedangkan untuk suasana interior menampilkan suasana dalam ruangan dengan bernuansa monokrom dan modern, pemilihan warna ruangan dan letak perabot juga disesuaikan lagi dengan fungsi ruang tersebut. dilihat di Gambar 17 dan 18.

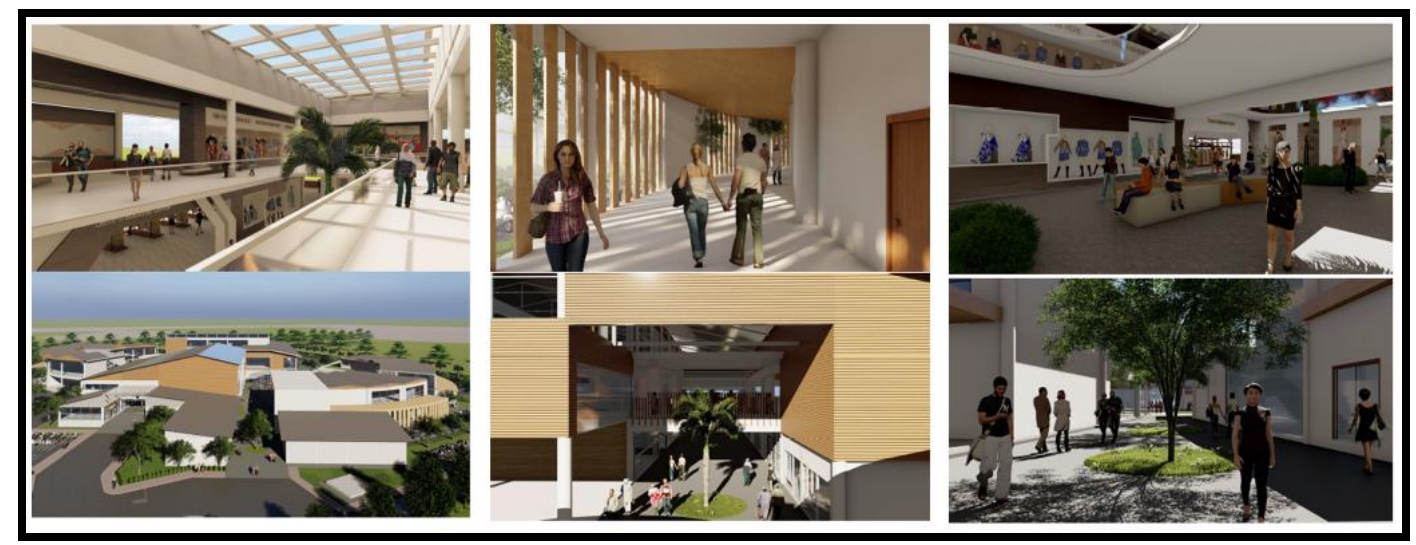

Gambar 17. Eksterior Pusat Mode di Kota Pontianak

Sumber: Penulis,2020

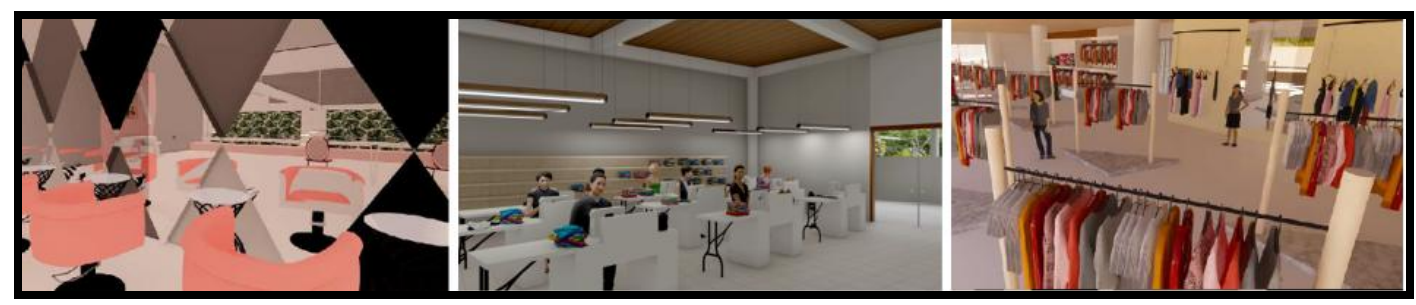

Gambar 18. Interior Pusat Mode di Kota Pontianak

Sumber: Penulis, 2020 


\section{Kesimpulan}

Perancangan Pusat Mode di Kota Pontianak ini merupakan perancangan sebuah wadah kegiatan mode yang memfasilitasi kegiatan komersil dalam hal mode, kemudian juga mewadahi segala kegiatan penunjang mode lainnya seperti promosi, edukasi, produksi dan rekreasi yang terletak pada satu lokasi. Menggunakan konsep City Walk menjadikan bangunan menjadi multimassa yang akan saling dihubungkan dengan jalur pedestrian dengan ruang terbuka hijau yang akan memberikan kesan asri dan rindang serta menjadi pembeda pusat mode ini dengan pusat perbelanjaan lainnya di Kota Pontianak.

\section{Ucapan Terima Kasih}

Ucapan syukur kepada Tuhan Yang Maha Esa atas Rahmat dan karunia-Nya, kepada orang tua penulis atas semangat dan dukungannya. Kepada dosen pembimbing Proyek Tugas Akhir yaitu Bapak Irwin, ST., MT. selaku pembimbing utama dan kepada Bapak Yudi Purnomo, ST., MT. selaku pembimbing pendamping yang telah memberikan evaluasi dan saran dalam proses perancangan pada penulis. Kepada seluruh teman-teman yang telah membantu memberikan dukungan dan doa dalam pengerjaan Proyek Tugas Akhir ini, penulis mengucapkan terima kasih sebanyak-banyaknya.

\section{Daftar Acuan}

Badan Pusat Statistik Kota Pontianak. (2019). Kota Pontianak Dalam Angka 2019. Pontianak: Badan Pusat Statistik Kota Pontianak.

Barnard, M. (2007). Fashion Sebagai Komunikasi. Yogyakarta: Jalasutra

Kamus Besar Bahasa Indonesia. (2020, 10 April). Pengertian Mode. Retrieved from https://kbbi.web.id/mode Kamus Besar Bahasa Indonesia. (2020, 10 April). Pengertian Pusat. Retrieved from https://kbbi.web.id/pusat

Krisnawati, E. (2013). Studi Keberadaan Citywalk Terhadap Fungsi Peruntukan. Jurnal Teknik Sipil dan Arsitektur $13(17$.

Nuraini, C., Sudrajat, I. (2010). Metode Perancangan Arsitektur. Bandung: Karya Putra Darwati

Wijaya, G.L. (2010). Bandung Fashion Center. Jurnal Arsitektur. 3-11 